\title{
Chapter 45 \\ ISLAND HARBOURS AND THEIR INFLUENCE \\ ON ADJACENT SHORES
}

\author{
Leon Shirdan \\ Director, Civil \& Marine Engineering Co. Ltd. \\ Haifa, Israel
}

The purpose of this paper is to put forward an alternative solution to the problem of reconstitution of existing ports, generally too shallow for the large tankers and ore carriers.

Usually, the existing moles are extended to deep water fairways and approaches to berths, docks and basins, dredged and adapted to the draught of the new giants. This is connected with enormous expenses. Sometimes completely new port units, as for instance Europort, are built.

The Island Harbours, with their seaward position, will reduce the length of the shipway to the berths and thus provide a speedier turn-out of vessels. The cost of erection and maintenance of such a harbour is in most cases lower than in that of a conventional solution, due to short breakwaters and limited quantities of primary and maintenance dredging operations.

Different alternatives of island ports can be adapted in most sandy coasts over the world.

The changes in coastal regime which may result from erecting an island harbour connected with the mainland by a bridge or a causeway can turn out profitable for general cargo ships, and even fisherboats, especially on the coasts where till now cutting the sea approaches through the shallows and bars was often unacceptable, due to the enormous expenses involved.

\section{GENERAL CONSIDERATIONS}

The maintenance of deep enough sea approaches to harbours built on shallow shores and in estuaries, with significant sand movement, will encounter with difficulties due to a large amount of permanent sedimentation which requires permanent dredging.

Keeping clear of sediments of a convenient and safe fairway cut in a shallow bank will be very difficult when the port is located in an 


\section{ISLAND HARBOURS AND THEIR INFLUENCE \\ ON ADJACEN'T SHORES}

area of frequent storms. In waters with gentle slope of the sea bed, with a channel leading to the port entrance, dredged through a bar, the quantities of sand or silt to be removed can grow to such an extent that the exploitation of such ports is no more profitable.

On shores with considerable tidal level difference, ships wanting to enter the harbour have often to wait for high water.

Even where the amplitude of ebb and flood levels is not so extensive, as for instance at Ijmuiden on the Dutch Coast, the entrance of large vessels into the harbour channel is possible during high water only.

The time wasted by ships awaiting the flood has been on the increase during the last decade, with the growing dimensions of ships. Thus free sailing of ships to and from a harbour is connected with obstacles, due to the lack of permanent approaches having a sufficient depth.

When bulk cargo or tank vessels are considered, speedy turnout if of highest technical and economical importance. Here, loss of time is of great disadvantage.

Today, tankers and carriers of 60,000 tons are no longer a novelty, and a large number of such ships are ordered. However, there are only several ports in the world where these vessels can freely enter, most existing accommodations being built to serve ships with a draught of not over 10 metres.

To handle the newly constructed giants, with draughts of 12.5 metres and over, a large-scale reconstitution is necessary. The fairways, entrances and inner parts of ports have to be deepened, enlarged and rebuilt. In many cases, new anchorages, or even harbours, have to be created to suit the changing conditions.

With the required depth at the entrance of more than 15 metres below MLWL as a function of ships draught and significant wave amplitude, the seaward extension of the moles up to 15-18 metres depth, or deepening of the fairway and its maintenance, will be prohibitively expensive.

Instead of these costly wo rks and a very high charge for constant dredging of the shipping lane, a roadstead island port, with the entrance at desired depths, can be erected in the vicinity of an exist- 


\section{COASTAL ENGINEERING}

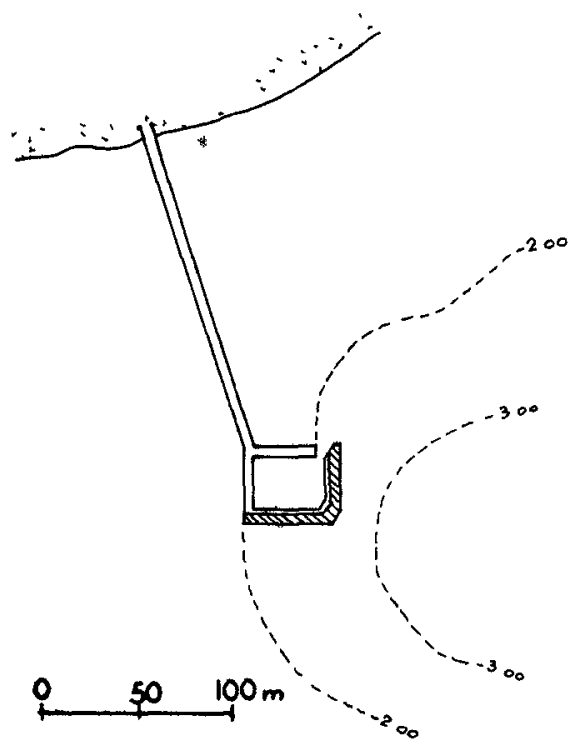

Fig. 1. Fishery harbour in Baltic Sea.

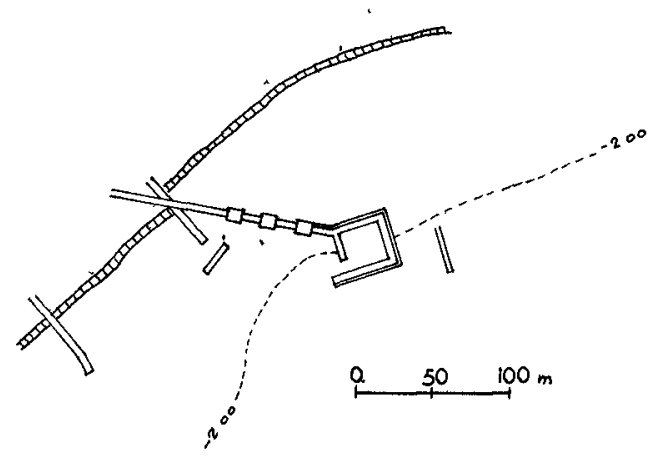

Fig. 1. Fishery harbour in Baltic. Sea.

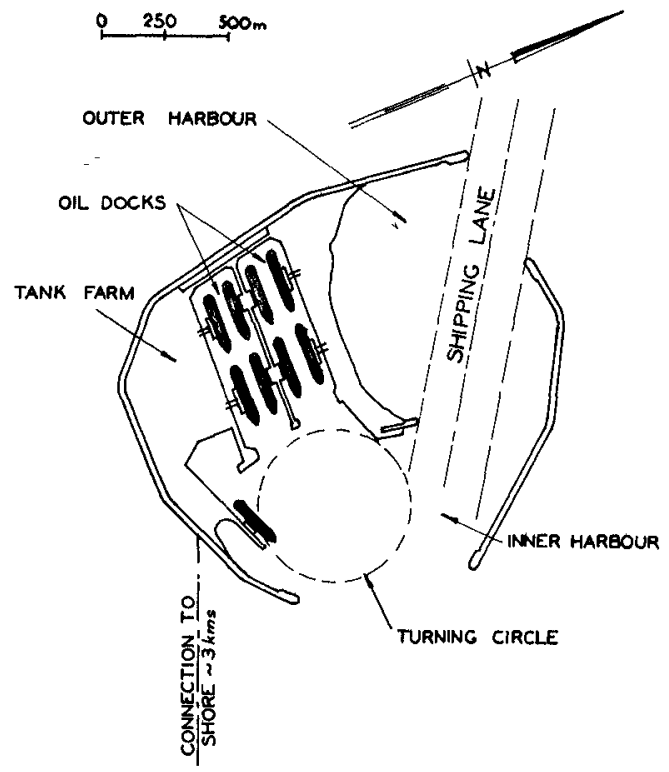

Fig. 4. Proposed oil port at Ijmuiden (Exercise study).

oil jetty at Moron. 


\section{ISLAND HARBOURS AND THEIR INFLUENCE ON ADJACENT SHORES}

ing harbour, or even as an independent unit. The cost of such a port will be lower than the conventional design, due to the comparatively reduced length of sheltering structures and lower primary and maintenance expenses.

The all-weather transloading of the cargo to and from the mainland can be provided by special sea-going barges, rope-ways, and even a bridge, if the traffic volume will justify it.

In the case of fluids and gases, connection with the coast should be by means of pipelines lying on the sea-bed or supported on a light structure. The island port will shelter the waters shorewards to a considerable extent, a factor which will facilitate communication with the coast.

The idea of an island harbour for large tankers was put forward by the author of this paper during the first International Course of $\mathrm{Hy}-$ draulic Engineering at Delft, when a team of graduate engineers was called upon to consider, as a study problem, a new oll port for Ijmuiden in the Netherlands. This idea was then further developed by a section of the team, namely Group 12, consisting of Messrs. G. de Campos, S. Muddappa, I. Shams, L. Shirdan, M. Vajda. Under the auspices of the Directors of the I.C.H.E. and the Hydraulics Laboratory at Delft a model of the port was built and tested in a basin.

\section{OFF-SHORE MOORINGS}

In ancient times, there already existed island harbours adjacent to the shore, for example in Tyre and Alexandria. Nowadays, such ports can be found -

(a) in arctic waters, the eastern cosst of the Caspian Sea, the Far East and the Baltic Sea (Bornholm island), etc. (Figures 1 and 2), as fishery harbours and bases, connected with the shore by means of a bridge or a causeway;

(b) on the Caspian Sea (USSR coast), on the Danish shore (Provesten), on the Adriatic Sea (Ancona), in Lake Maracaibo (La Salina), etc.

as oil harbours, bases and moorings;

(c) all over the world

as loading and unloading installations for bulk cargo. 


\section{COASTAL ENGINEERING}

Mostly, offshore anchorages and installations are built in open waters, not too exposed to stormy seas.

This is the case with submarine pipe-lines with buoy moorings, dolphin berths, berthing beams, loading towers etc ., adapted where there is no deep water near the coast. Successful examples have been in existence for many years at Tripoli, Banias, Haifa, as well as elsewhere throughout the world.

However, because of the small dimensions of these installations and their great distance from the shore, their influence on the coastal regime is practically negligible.

Where the frequency of storms makes unsheltered moorings risk and uneconomical, the berthing of large and very expensive oil tankers and ore carriers calls for protection against wind attacks, waves and current action.

The development of these kinds of harbours can vary from a straight short breakwater, parallel to the shore and protecting one ship only (as designed by Messrs. Royal Netherland Harbour Works for the tanker berth opposite the refinery at Mor on in Venezuela (Fig. 3)) to large, independent island ports with a diameter of $2.0 \mathrm{kms}$ and more.

\section{IJMUIDEN OIL PORT}

As mentioned above, a study for a new Oil Port at Ijmuiden was carried on during 1958. The possibility of an island harbour in the vicinity of the existing port and industrial area was brought forth by the author and elaborated with the help of Group 12.

The principle was to locate a deep water harbour directly in the area of $-15 \mathrm{~m}$ isobaths.

The coast in questinn, open to the North Sea, has a mildly sloping sandy bed and is visited by frequent storms, tidal currents and large sediment transport.

It was required to provide a sheltered sea terminal, with straigh and safe approaches for tankers of over 60,000 tons, and with the possibility of extension in the future. Also a small transit storage tank farm has to be provided. 


\section{ISLAND HARBOURS AND THEIR INFLUENCE ON ADJACENT SHORES}

The conventional solution was to lengthen the moles of the existing harbour far seawards, enlarging and dredging the fairway and entrance, and building an oil terminal inland.

This would mean extremely expensive works, connected with the altering of the breakwaters, widening and deepening of outer and inner channels, and extensive maintenance dredging in the future of the depths in the approaches.

The alternative above-mentioned solution of the island harbour considered at first straight breakwater, parallel to the shore, with berths on the landward side. However, as the strong shorewise tidal currents in the area would have interfered with the moorings, the design has been developed towards a nearly circular form of about $2 \mathrm{kms}$ in diameter (Fig. 4).

The seaward position of the terminal should enable the entering and leaving of the harbour, mooring works, discharging and subsidiary operations to be executed in a considerable shorter time than in case of a conventional harbour (hence a much speedier turn-out of ships). The help of the tug boats is also reduced to a minimum.

The berths are well protected against waves, wind action and currents, in spite of their distance of less than $2 \mathrm{kms}$ from the harbour entrance.

The prevailing waves come from directions between south and west, but the group of storm waves of low frequency but of considerable height comes usually from the northwest to north sector, due to the wind velocity and the corresponding fetch..

The waves originated by offshore winds are almost insignificant. Therefore, the most favourable direction of the shipping lane was toward NNW, lying in the direction of dominant storms and protecting the incomong and outgoing ships from prevailing winds and waves.

\section{MODEL INVESTIGATIONS}

Model investigations have shown that even the highest waves penetrating in direct incidence through the entrance from the northwestern sector are losing height and disperse to a great extent their energy on the spending beach in the outer harbour before reaching the inside aquatory of the port and the turning circle. The shape of the outer 


\section{COASTAL ENGINEERING}

harbour and the profile of the spending beach played a dominant role in this phenomenon.

The wave height recorded in model experiments was in the berthing docks much lower than $10 \%$ of incidental original wave height, so the conditions for mooring and working are acceptable.

Wave heights up to $40 \%$ were measured in the inner harbour during the most unfavourable waves penetration, but the turning circle itaelf was always beyong the $20 \%$ aqui-height line of the incoming waves .

The damping of waves in the model was remarkably positive during direct incidence towards the spending beach, resulting in a considerable wave height reduction, and it appears that waves higher than $40 \%$ cannot reach the inner harbour.

The shorewards wide opening between the breakwaters has almost eliminated the possibility of waves reflection in the port itself. This auxiliary entrance permits a partly sheltered communication with the mainland.

Water area sheltered by the island extended far behind, almost to the coast. Slightly less than $20 \%$ wave height, extending to more than one diameter of the island, was indicated in the model.

The Influence of the Island Ports on the Adjacent Shores. The model study of the affect of the harbour on the coast opposite was not extensive enough, due to lack of time.

Without doubt, considerable changes will be caused on the adjacent shores, decreasing however with the growing distance of the island from the mainland.

The influence will be very strong in the event of a narrow channel between the harbour and shore. It will probably greatly differ in every case, and it will depend on a coastal regime in places under consideration.

In every separate case the stabilization of the coastal regime will depend on the distance from the shore, wave characteristics, the presence of tides and longshore currents, the quantities of the sediment transportation etc.

Where strong longshore currents are absent, a sunbulb may form 


\section{ISLAND HARBOURS AND THEIR INFLUENCE ON ADJACENT SHORES}

at the edge of the island, directed towards the shore, as a result of wave refraction.

At the same time, a sandbar from deposited debris may form opposite the shore. In some cases this process may continue until both promontories meet, forming a tombolo which connects the harbour with the mainland. This may happen when the island is built in the direct vicinity of the shore.

However, in tidal waters where strong cross-currents exist, a channel across the bar will keep the gap open, permitting the shorewise streams to pass in either direction. Thus sediment transportation along the coast will not stop and the coastal regime will remain almost unchanged.

\section{CONCLUSIONS}

An artificial island-port in stormy areas can be put forward as a solution to avoid:

(a) Prohibitive expenses connected with the adaption of existing harbours to new super-tankers and ore carriers;

(b) Costly primary and maintenance dredging;

(c) Acquienitita of additional areas on the mainland;

(d) Ship dedigg, , due to the far distance from the sea to the terminal inland;

(e) Drastically quick changes in coastal regime.

The advantages of the proposed island-harbour are:-

(a) Entrance at the natural depth, reducing primary and maintenance dredging to a minimum;

(b) Comparatively low cost of construction, due to shorter length of breakwaters;

(c) Speedy turn-out of vessels, due to short and straight ship lanes from harbour entrance to moorings; 
(d) Additional navigation safety, due to seaward situation of the entrance on the $15-\mathrm{m}$ contour-line, providing sufficient space for ships in deep water to make a fuill turn, for a second trial, if they did not succeed to enter because of unfavourable weather conditions. Furthermore, the current velocities in front of the entrance will be much lower than in conventional solution.

(e) The changes in the coastal regime should be slower. In many cases, the sediment transport will be maintained for the greater part. Thus additional shore protection along the coast of the mainland will not be required.

\section{REFERENCES}

Oil Port at Ijmuiden, Island harbour by Group 12; I.C.H.E. Delft 1958 .

Island-harbour Model, Oil Port - Ijmuiden. Report on Investigation of Agitation; S 51, Waterloopkundig Laboratorium, Delft 1958.

XVIIth International Navigation Congress - Lisbon 1949 - Section II, Question II.

"Offahore Terminal Built on Man-made Island" - "World Contribution", 1958 .

Breakwater Investigation at Moron (Puerto Cabello), Waterloopkundig Laboratorium, Delft 1958.

The Iraq-Mediterranean Pipeline, I.P.C. 1934, Haifa, Israel.

Various B.P. and I.P.C. publications.

Iraq Petroleum Company Ltd., London 1935, Loading Regulations at Terminals Tripoli and Haifa.

The Dock \& Harbour Authority, May 1957.

The Dock \& Harbour Authority, December 1958.

Sviderski, P. A. (1955), Ustroistvo i expluatatia ryboprom sylovych portovi baz, Part I. Pistchepromizdat, Moscow, pp 206-211.

Johnson, D. W. (1919), Shore processes and shoreline development. Chapman-Hall Ltd., London.

Bryla, S. i Bryla J. (1956), Tablice Inzynierskie Vol. IV Budownictwo Morskie P.W.N. Poznan, Szozecin. 